\title{
Influence of Cold-Hardening and Soil Matric Potential on Resistance to Speckled Snow Mold in Wheat
}

Zenta Nishio, National Agricultural Research Center for the Hokkaido Region (Memuro), Shinsei, Memuro, Hokkaido 082-0071, Japan, and Department of Plant Pathology, Washington State University, Pullman 99164; Norio Iriki, National Institute for Crop Science, 2-1-18 Kannondai, Tsukuba, Ibaraki, 305-8518, Japan; Kanenori Takata, National Agricultural Research Center for Western Region, 6-12-1 Nishi-Fukatsucho Fukuyama, Hiroshima 7218514, Japan; Miwako Ito and Tadashi Tabiki, National Agricultural Research Center for the Hokkaido Region (Memuro), Japan; and Timothy D. Murray, Department of Plant Pathology, Washington State University, Pullman

\begin{abstract}
Nishio, Z., Iriki, N., Takata, K., Ito, M., Tabiki, T., and Murray, T. D. 2008. Influence of coldhardening and soil matric potential on resistance to speckled snow mold in wheat. Plant Dis. 92:1021-1025.

The influence of soil matric potential, cold-hardening temperature, and duration on resistance to speckled snow mold caused by Typhula ishikariensis in wheat was investigated. Six winter wheat lines were subjected to cold-hardening temperatures of 2 or $4^{\circ} \mathrm{C}$ for $1,2,3$, or 4 weeks with soil matric potential of -0.1 or $-0.01 \mathrm{MPa}$. Plants were inoculated with T. ishikariensis after cold-hardening, incubated at $10^{\circ} \mathrm{C}$ for 25 days in the dark, and then evaluated for regrowth. Overall recovery from snow mold was least when plants were hardened at $2^{\circ} \mathrm{C}$ for 1 week at $-0.01 \mathrm{MPa}$ and greatest when hardened at $4^{\circ} \mathrm{C}$ for 4 weeks at $-0.1 \mathrm{MPa}$. Survival of plants following snow mold was greater when plants were cold-hardened at 4 than at $2^{\circ} \mathrm{C}$ and at -0.1 than $-0.01 \mathrm{MPa}$ soil matric potential. The greatest difference in survival among lines and correlation with field observations occurred when plants were hardened at $4^{\circ} \mathrm{C}$ at $-0.1 \mathrm{MPa}$ matric potential for 3 weeks. Understanding the influence of temperature and soil matric potential during coldhardening on speckled snow mold resistance will be useful to breeding programs developing snow-mold-resistant cultivars under controlled environment conditions.
\end{abstract}

Additional keywords: artificial inoculation, Triticum aestivum

Snow mold diseases affect plants exposed to prolonged snow cover, resulting in destruction of leaves and crown tissues. Winter wheat (Triticum aestivum L.) and other small grains and grasses suffer from snow mold diseases in the northern boundary areas of their cultivation, including the Pacific Northwest region of the United States; Hokkaido, Japan; and western Canada, where deep snow can persist over 4 months $(4,13,27)$. Fungicides can be used to control snow molds, but they are costly and disease development is unpredictable due to variability in autumn and winter weather favorable for disease development. For this reason, the use of snow-moldresistant cultivars has been the most im-

Corresponding author: T. D. Murray

E-mail: tim_murray@wsu.edu

PPNS No. 0465, Department of Plant Pathology, College of Agricultural, Human, and Natural Resource Sciences Agricultural Research Center, Project No. WNP0670, Washington State University, Pullman 99164-6430.

Accepted for publication 11 February 2008.

doi:10.1094/PDIS-92-7-1021

(C) 2008 The American Phytopathological Society portant method of controlling these diseases.

Snow molds are caused by several different fungal pathogens, including Typhula ishikariensis S. Imai var. ishikariensis and T. idahoensis Remsberg (speckled snow mold), T. incarnata Lasch (gray snow mold), Monographella nivalis (Schaffnit) E. Müll. var. nivalis (anamorph Microdochium nivale (Fr.) Samuels \& I.C. Hallet) (pink snow mold), Pythium spp. (Pythium snow rot), and Coprinus psychromorbidus (cottony snow mold or nonsclerotial lowtemperature basidiomycete) (12). Of these, speckled snow mold is the most common in the Pacific Northwest of the United States and Hokkaido, Japan (1,4,5,8, 15,27). In Hokkaido, which produces over $60 \%$ of the domestic wheat in Japan, yield losses up to $67 \%$ and over $20 \%$ of fields with damage due to snow mold diseases have been reported (1).

The severity of snow mold diseases is strongly influenced by the duration of snow cover, cold-hardening conditions prior to snow fall, and whether soil is frozen when snow cover begins. The conventional methods of screening for snow mold resistance in field plots were improved by using several rates of inoculum $(1,4,15)$. Nevertheless, development of snow mold is erratic because of the variation in environmental conditions favorable to the development of snow mold diseases.

Breeding snow-mold-resistant cultivars could be accelerated with artificial snow mold resistance tests conducted under controlled conditions in growth chambers. Artificial inoculation with pathogencolonized inoculum and simulated snow cover by moist cotton has been used to identify plants resistant to speckled snow mold, gray snow mold, and pink snow mold $(1,8,11,18,20,23)$. The time required for such tests was reduced significantly by using optimum temperatures for growth of the pink and gray snow mold pathogens rather than conditions that exist under snow (i.e., $0^{\circ} \mathrm{C} ; 23$ ).

Cold-hardening has proven to be indispensable for the development of snow mold resistance with controlled environment techniques $(12,13,20,24,25)$. Nakajima and Abe (25) described the influence of cold-hardening temperatures and light intensity on snow mold resistance and found that incubating at $2^{\circ} \mathrm{C}$ resulted in more rapid development of snow mold resistance than at $6^{\circ} \mathrm{C}$. They also found that low light intensity $\left(150 \mu \mathrm{mol} \mathrm{m} \mathrm{m}^{-2} \cdot \mathrm{s}^{-1}\right)$ was necessary for development of resistance but duration of light did not affect the expression of resistance.

Soil matric potential has a significant effect on both pathogen survival and development of soilborne diseases such as Cephalosporium stripe under controlled environment conditions (2). Specht and Murray (26) reported that soil matric potentials between -0.06 and $-0.01 \mathrm{MPa}$ had a significant influence on development of Cephalosporium stripe of wheat, with wetter soil resulting in greater disease than drier soil. Exposure of winter wheat seedlings to desiccation stress induced the same degree of freezing tolerance as coldhardening for 4 weeks at $2^{\circ} \mathrm{C}(10)$, and survival of resistant cultivars was greater following wet rather than dry autumn weather (4). Thus, soil matric potential may influence the development of resistance to snow mold; however, its effect on development of snow mold resistance has not been examined under controlled environment conditions. 
In order to develop a reliable snow mold inoculation technique under a controlled environment, it is necessary to understand the effects of soil matric potential, coldhardening temperature, duration of coldhardening conditions, and potential interactions among these factors on the expression of resistance to $T$. ishikariensis. Nakajima and Abe (24) reported that exposure to temperatures below $5^{\circ} \mathrm{C}$ is important for cold-hardening, and some studies reported decreased survival with intermediate coldhardening durations $(4,9,13,25)$. The expression of snow mold resistance may be improved by more accurate temperature and soil matric potential control during the cold-hardening treatment. Thus, we investigated the influence of soil moisture at $-0.01 \mathrm{MPa}$ (wet soil) or $-0.1 \mathrm{MPa}$ (dry soil) with cold hardening temperatures of 2 or $4^{\circ} \mathrm{C}$ that lasted from 1 to 4 weeks on expression of resistance to speckled snow mold. These soil matric potentials were chosen because they simulate autumn soil moisture in areas where snow mold is common, and cold-hardening temperatures below $5^{\circ} \mathrm{C}$ are necessary for inducing snow mold resistance (24).

\section{MATERIALS AND METHODS}

Plant materials. Six winter wheat lines ranging from very resistant to very susceptible to speckled snow mold were used in all experiments (Table 1). PI173438 is a highly resistant line from Turkey $(1,8,13-$ 15,17,18,23-25,31). Cv. Münstertaler, from Switzerland, is highly resistant to snow mold and is freezing tolerant $(13,16,21,22)$. Cv. Sprague was developed in the U.S. Pacific Northwest from a cross of the highly snow-mold-resistant line PI181268 and cv. Gaines, which has moderate resistance to snow mold $(4,13)$. Horoshirikomugi, with moderate resistance $(1,15,17,22,23)$ and Chihokukomugi, with less resistance $(1,15$, $17,18,22,23,31)$ to snow mold are cultivars from Japan; Ibis is a very susceptible cultivar from Holland $(1,15,17)$.

Cultural conditions and coldhardening. Five seedlings of each line were transplanted into a pot $(12.7 \mathrm{~cm}$ in diameter) containing $1,200 \mathrm{~g}$ (air-dry equivalent) of Thatuna silt loam soil mix, vermiculite, and washed river sand (90:5:5, wt/wt) after imbibition for 4 days at $4{ }^{\circ} \mathrm{C}$. Slow-release fertilizer ( $2 \mathrm{~g}$; Osmocote Pro
20-4-8 with IBDU and minor nutrients; The Scotts Company, Marysville, $\mathrm{OH}$ ) was applied to each pot and plants were grown for 2 weeks at $20^{\circ} \mathrm{C}$ (prehardening). Light intensity during prehardening was adjusted to $350 \mu \mathrm{mol} \cdot \mathrm{m}^{-2} \mathrm{~s}^{-1}$ with a 12 -h photoperiod.

Cold-hardening was conducted with soil matric potentials of -0.1 or $-0.01 \mathrm{MPa}$ at 2 or $4^{\circ} \mathrm{C}$ for $1,2,3$, or 4 weeks in a Conviron GR48 growth room (Conviron Controlled Environments Limited, Winnipeg, Canada) capable of controlling temperature to $\pm 0.5^{\circ} \mathrm{C}$. Under these conditions, soil temperature in pots equilibrates to cold-hardening temperature in $4 \mathrm{~h}$ or less (T. D. Murray and D. Z. Skinner, unpublished data), Soil moisture was adjusted to the desired matric potentials gravimetrically based on a soil moisture release curve (2) and measured with a dewpoint hygrometer (SC-1OA and NT-3 nanovoltmeter; Decagon Devices, Inc. Pullman, WA). Soil was saturated, allowed to dry to the desired water potential before cold-hardening began, and then maintained at that value during cold-hardening by watering gravimetrically every 2 days $(2,26)$. Light intensity during cold-hardening was adjusted to $330 \mu \mathrm{mol}$ $\mathrm{m}^{-2} \mathrm{~s}^{-1}$ with an $8-\mathrm{h}$ photoperiod. Tiller number per plant was determined after coldhardening, prior to inoculation.

Inoculation and evaluation of recovery from disease. Isolate TB12 of T. ishikariensis biotype $\mathrm{B}$, isolated in Sapporo, Japan with high virulence to wheat, was cultured on potato dextrose agar (PDA) at $10^{\circ} \mathrm{C}$ for 1 week in petri dishes $(15,19)$. A small piece of hyphae was transferred to sterile oat kernels and cultured for 30 days at $10^{\circ} \mathrm{C}$. Pathogen-colonized oat kernels and bran vermiculite media (5 g, 1:1) were spread on the soil surface of each pot following cold-hardening. Plants were covered with $15 \mathrm{~cm}^{2}$ of wet cotton (approximately $25 \mathrm{~g}$ of dry weight) and then incubated at $10^{\circ} \mathrm{C}$ for 25 days in the dark $(18,23)$, after which pots were moved to a greenhouse at $20^{\circ} \mathrm{C}$ and the cotton removed. Tiller number per plant was determined and tillers then were cut $5 \mathrm{~cm}$ above the soil line 3 days after removal of the cotton. Survival was evaluated by determining the percentage of tillers that regrew 1 week after cutting.

Each experiment was arranged in a twoby-two-by-four (soil matric potential-

Table 1. Origin and resistance reactions of winter wheat lines to speckled snow mold

\begin{tabular}{llcl}
\hline Line & \multicolumn{1}{c}{ Origin $^{\mathbf{a}}$} & Resistance $^{\mathbf{b}}$ & \multicolumn{1}{c}{ References } \\
\hline PI173438 & Turkey & VR & $1,8,13-15,17,18,23-25,31$ \\
Münstertaler & Switzerland & VR & $13,16,21,22$ \\
Sprague & United States & R & 7,13 \\
Horoshirikomugi & Japan & MR & $1,14,17,22,23$ \\
Chihokukomugi & Japan & S & $1,14,17,18,22,23,31$ \\
Ibis & Holland & VS & $1,14,17$ \\
\hline
\end{tabular}

${ }^{\text {a }}$ United States $=$ Washington State and Japan $=$ Hokkaido Prefecture.

${ }^{\mathrm{b}}$ Resistance to speckled snow mold in field experiments is based on visual estimation of the extent and vigor of recovery after snow melt as described in the listed references. $\mathrm{VR}=$ very resistant, $\mathrm{R}=$ resistant, $\mathrm{MR}=$ moderate resistance, $\mathrm{S}=$ susceptible, and VS = very susceptible. temperature-duration) factorial design using a randomized complete block design with four replicates, where blocks were separated by a space in the growth chamber. Individual pots represented the experimental units (plots). The experiment was conducted twice and data represent the means of the two experiments (a mean of eight pots per wheat line). Analysis of variance (AOV) was performed and a Tukey-Kramer Multiple range test or Student's $t$ test used to differentiate treatment means of the two experiments. The data from both experiments were combined for AOV after homogeneity of variance was tested and found to be not significantly different between experiments.

\section{RESULTS}

Influence of cold-hardening temperature and soil matric potential on plant growth. A significant interaction was observed between cold-hardening temperature and duration at $-0.01 \mathrm{MPa}$ soil matric potential $(P<0.05)$ for tiller number. Temperature and soil matric potential did not influence tiller number with 1 and 2 week of cold-hardening (Fig. 1); however, more tillers developed on plants coldhardened at -0.01 than $-0.1 \mathrm{MPa}$ with 3 and 4 weeks of cold-hardening. More tillers also developed at 4 than $2{ }^{\circ} \mathrm{C}$ when plants were cold-hardened for 4 weeks; the differences were statistically significant at both soil matric potentials (Fig. 1).

Influence of cold-hardening temperature and soil matric potential on plant survival after speckled snow mold. Coldhardening temperature, matric potential, and line all had significant effects on survival, which was greater at 4 than at $2{ }^{\circ} \mathrm{C}$ and at -0.1 than at $-0.01 \mathrm{MPa}$ (Fig. 2). A significant interaction was observed between soil matric potential and cold hardening duration at both cold-hardening temperatures $(P<0.01)$ for plant survival. Plants that were cold-hardened for 4 weeks had the greatest survival, those coldhardened for 1 week had the least survival, and plants cold-hardened for 2 and 3 weeks were intermediate in survival (Fig. 2). At $-0.01 \mathrm{MPa}$, survival was always significantly greater at 4 than at $2{ }^{\circ} \mathrm{C}$; there was no significant difference in survival between temperatures at $-0.1 \mathrm{MPa}$. Survival at $-0.1 \mathrm{MPa}$ was greater than at $-0.01 \mathrm{MPa}$ at both 2 and $4^{\circ} \mathrm{C}$. Soil matric potential had a significant impact on survival for 1,2 , and 3 weeks of coldhardening at $2^{\circ} \mathrm{C}$, with greater survival occurring at -0.1 than $-0.01 \mathrm{MPa}$. At $4^{\circ} \mathrm{C}$, survival at $-0.1 \mathrm{MPa}$ was greater than $-0.01 \mathrm{MPa}$ only with 1 week of coldhardening.

In general, the resistant lines PI173438 and Münstertaler had the greatest survival regardless of cold-hardening temperature or soil matric potential. PI173438 had the greatest survival followed by Münstertaler, 
whereas Ibis and Chihokukomugi had the least (Fig. 3). In contrast, survival of the susceptible lines was less at 2 than at $4^{\circ} \mathrm{C}$ and at -0.01 than at $-0.1 \mathrm{MPa}$ (Fig. 3).
Overall, the greatest difference in survival among lines occurred when plants were cold-hardened at $4^{\circ} \mathrm{C}$ with $-0.1 \mathrm{MPa}$ soil matric potential for 3 weeks (Fig. 3).

\section{DISCUSSION}

Cold-hardening at $4{ }^{\circ} \mathrm{C}$ with $-0.1 \mathrm{MPa}$ soil matric potential resulted in greater tiller number per plant and more effective

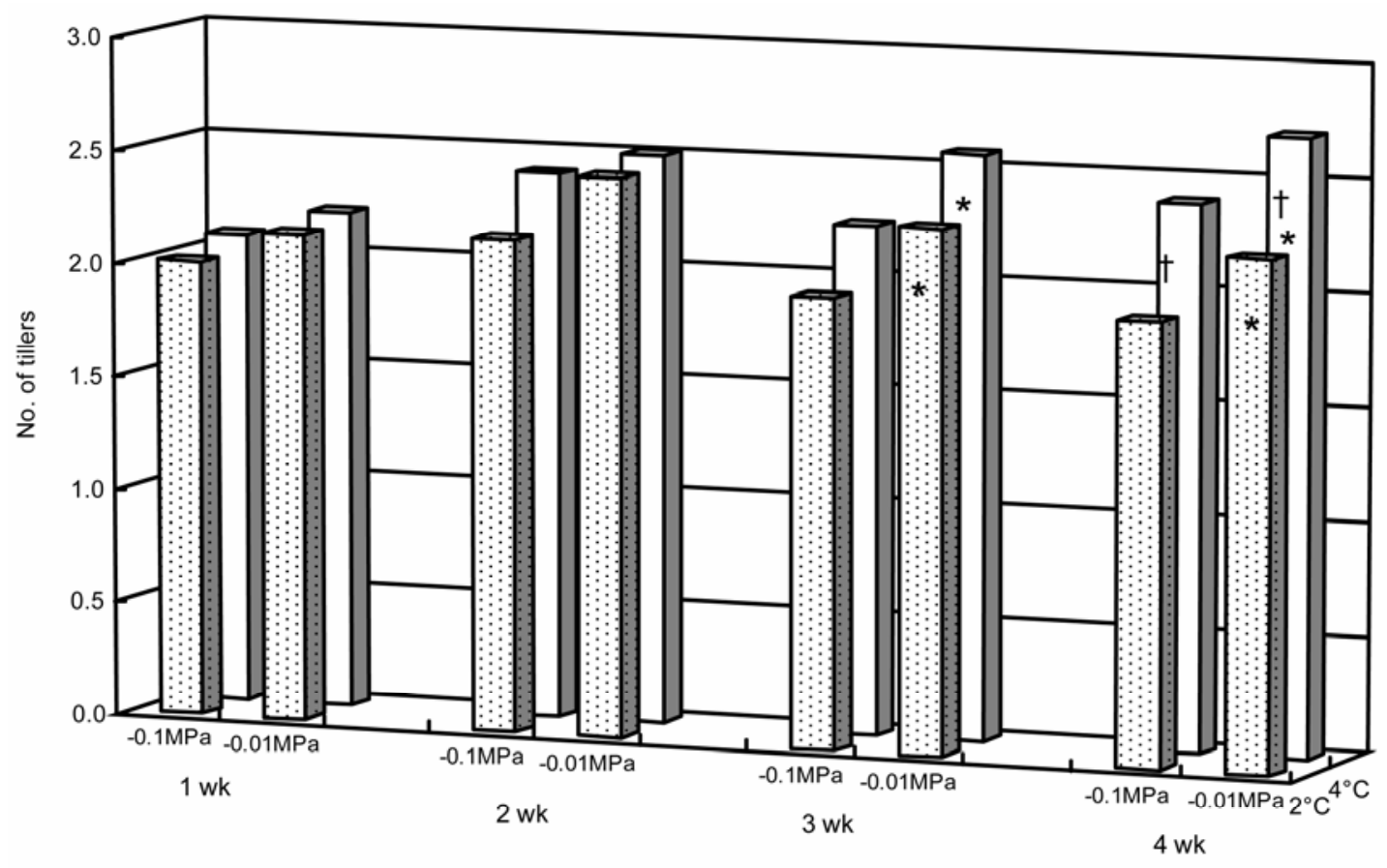

Soil matric potential and duration of cold-hardening

Fig. 1. Number of tillers per plant for winter wheat cold-hardened for $1,2,3$, or 4 weeks at 2 or $4^{\circ} \mathrm{C}$ and -0.01 or -0.1 MPa soil matric potential. Values represent the mean of six lines across two experiments with four replicates each; $\dagger=$ significant difference between temperatures based on paired Student's $t$ test at $P=0.05 ;^{*}=$ significant difference between soil matric potentials based on paired Student's $t$ test at $P=0.05$.

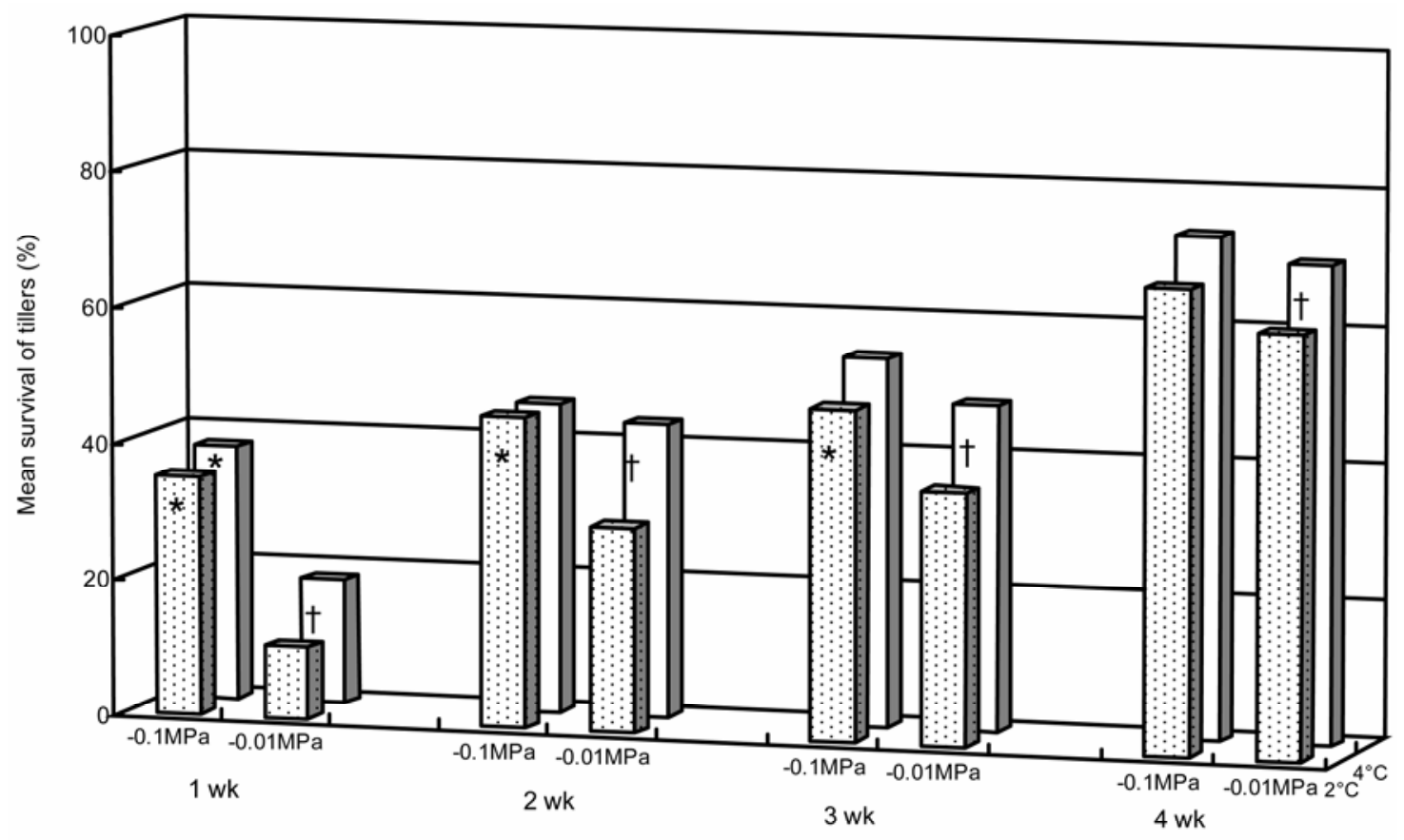

Soil matric potential and duration of cold-hardening

Fig. 2. Survival of tillers of wheat cold-hardened for $1,2,3$, or 4 weeks at 2 or $4{ }^{\circ} \mathrm{C}$ and -0.01 or $-0.1 \mathrm{MPa}$ soil matric potential followed by inoculation with Typhula ishikariensis. Values represent the mean of six lines across two experiments with four replicates each; $\dagger=$ significant difference between temperatures within a time period and a soil matric potential based on paired Student's $t$ test at $P=0.05 ; *=$ significant difference between soil matric potentials within a time period and a temperature based on paired Student's $t$ test at $P=0.05$. 
snow mold resistance, as reflected by greater plant survival, compared with $2^{\circ} \mathrm{C}$ and -0.01 MPa (Figs. 1, 2, and 3). Soil matric potential influenced plant survival when duration of cold-hardening was longer than 3 weeks. The difference in plant survival when cold-hardened at 2 and $4^{\circ} \mathrm{C}$ was less when plants were coldhardened at $-0.1 \mathrm{MPa}$ than at $-0.01 \mathrm{MPa}$ soil matric potential. Cold-hardening temperature resulted in a statistically significant greater number of tillers in the 4 weeks of cold-hardening, which likely is due to the larger accumulated degree days at 4 than at $2^{\circ} \mathrm{C}$ (Fig. 1). Although the greater number of tillers illustrates the importance of optimizing cold-hardening conditions to differentiate the snow mold resistance among lines, this difference is not considered biologically significant for snow mold resistance. Austin and Jones (3) reported that $3^{\circ} \mathrm{C}$ is the minimum temperature for calculating accumulated degreedays for wheat. In this study, more than 4 weeks of cold-hardening was necessary for significant differences among lines in tiller number at both cold-hardening temperatures.

Our results demonstrate that survival is greater with a longer cold-hardening pe- riod but that this is not significantly correlated with tiller number, which did not increase significantly with increasing duration of cold-hardening. Previous studies have reported a positive association between plant size and resistance to snow mold $(4,6,12)$. Based on our results, 3 weeks of cold-hardening was sufficient for the expression of resistance and useful for evaluation of snow mold resistance.

Snow-mold-resistant winter wheat cultivars accumulate polysaccharides more rapidly and in greater quantities than susceptible cultivars during cold-hardening (20,31). Plant fresh weight and tiller number during prehardening were greater with higher (warmer) cold-hardening temperature, and these factors had a positive correlation with resistance to cottony snow mold (12). Nakajima and Abe (24) reported that cold-hardening temperatures below $5^{\circ} \mathrm{C}$ are indispensable for the expression of snow mold resistance, and that some cultivars such as PI 173438 require a lower cold-hardening temperature for full expression of resistance (25). However, they also reported that higher temperature during cold-hardening resulted in larger plants, which was correlated to pink snow mold resistance (24).
Recent studies have reported that several transcriptionally regulated genes are upregulated by low temperature and drought stress and that stress-responsive networks function in the expression of plant stress tolerances $(29,30)$. The mechanism of snow mold resistance induction by lowtemperature and moisture stress may be further clarified by analyzing the expression of stress-responsive genes.

Artificial inoculation techniques have been developed for pink snow mold, gray snow mold, cottony snow mold, and speckled snow mold $(11,13,18,23,25)$. Previous researchers have concluded that resistance in winter wheat to speckled snow mold, pink snow mold, and gray snow mold are correlated $(1,4,17,28)$. In this study, the influence of two cold-hardening temperatures at four durations and two soil matric potentials on survival following snow mold was studied in an effort to optimize environmental factors to test lines for resistance. The greatest differences in survival among lines and the closest association with the ranking of resistance (PI 173438, Münstertaler > Sprague, Horoshirikomugi $>$ Chihokukomugi > Ibis) based on field tests $(1,4,15,16)$ occurred when plants were hardened at $4^{\circ} \mathrm{C}$ with $-0.1 \mathrm{MPa}$ matric
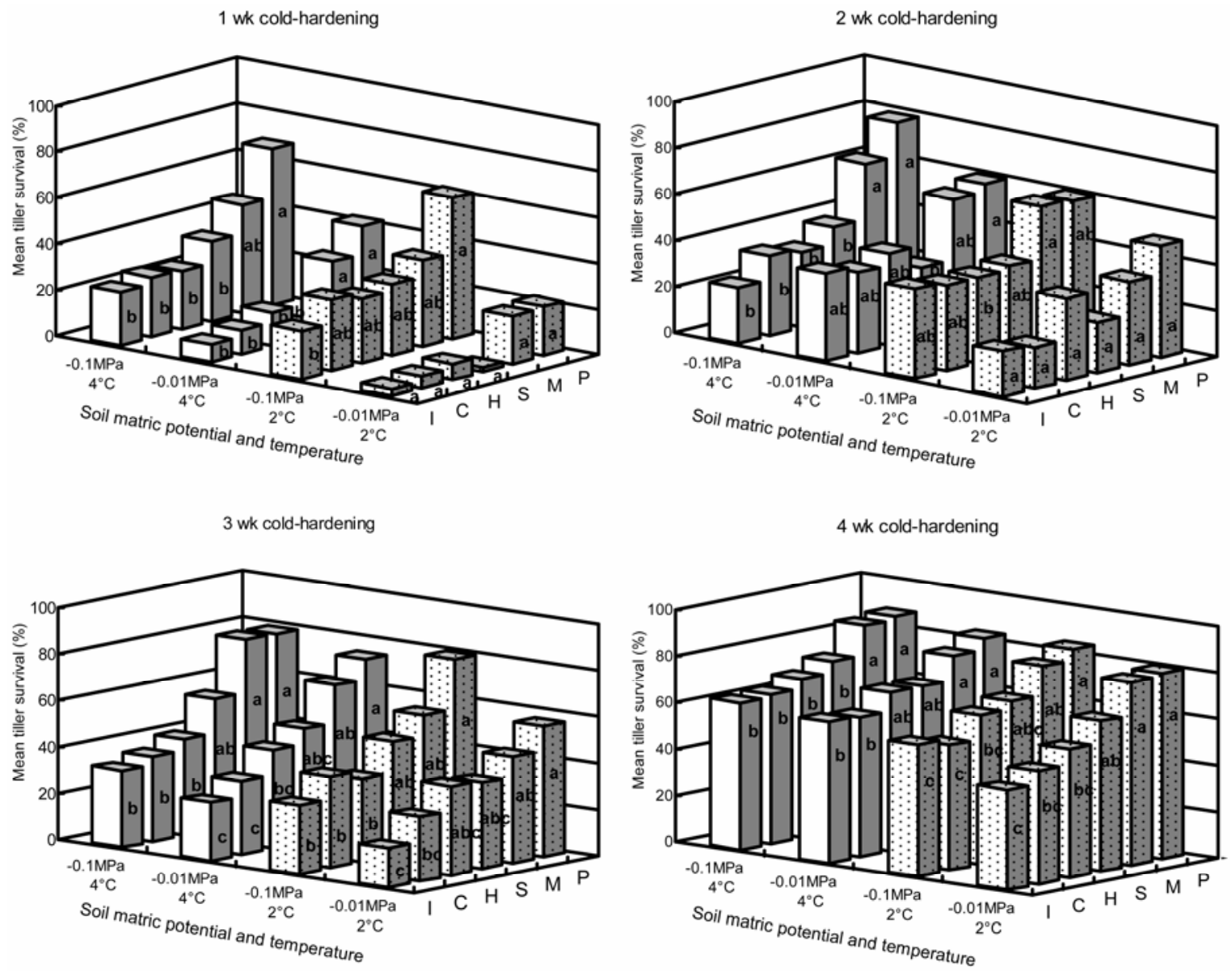

Fig. 3. Survival of tillers of wheat cold-hardened for $1,2,3$, or 4 weeks at 2 or $4^{\circ} \mathrm{C}$ and -0.01 or $-0.1 \mathrm{MPa}$ soil matric potential followed by inoculation with Typhula ishikariensis. Values represent the mean of two experiments with four replicates each. Values followed by the same letters were not significantly different in the same cold-hardening treatment according to Tukey-Kramer multiple range test at $P=0.05$. Cultivars: $\mathrm{P}=\mathrm{PI} 173438, \mathrm{M}=\mathrm{Münstertaler,} \mathrm{H}=$ Horoshirikomugi, $\mathrm{S}=$ Sprague, $\mathrm{C}=$ Chihokukomugi, and $\mathrm{I}=\mathrm{Ibis}$. 
potential for 3 weeks. The reaction of snow-mold-resistant lines differed from those of susceptible lines and a set of conditions for screening for speckled snow mold resistance were identified that allows these differences to manifest themselves and should benefit breeding programs trying to improve snow mold resistance.

\section{ACKNOWLEDGMENTS}

We thank the Washington State Wheat Commission for partial financial support; and H. Sheng, S. McDonald, J. Carson, and D. Skinner for their assistance. We thank N. Matsumoto for providing cultures of snow mold pathogens.

\section{LITERATURE CITED}

1. Amano, Y. 1987. Studies on methods of breeding wheat for winter hardiness. Bull. Hokkaido Prefect. Agric. Exp. Stn. 64:1-79.

2. Anderegg, J. C., and Murray, T. D. 1988. Influence of soil matric potential and soil $\mathrm{pH}$ on Cephalosporium stripe of winter wheat in the greenhouse. Plant Dis. 72:1011-1016.

3. Austin, R. B., and Jones, H. G. 1975. The physiology of wheat. Pages 20-73 in: Plant Breed. Inst. Annu. Rep. 1974. Plant Breeding Institute, Cambridge, UK.

4. Bruehl, G. W. 1982. Developing wheats resistant to snow mold in Washington State. Plant Dis. 66:1090-1095.

5. Bruehl, G. W., and Cunfer, B. 1971. Physiologic and environmental factors that affect the severity of snow mold of wheat. Phytopathology 61:792-799.

6. Bruehl, G. W., Kiyomoto, R., Peterson, C., and Nagamitsu, M. 1975. Testing winter wheats for snow mold resistance in Washington. Plant Dis. Rep. 59:566-570.

7. Bruehl, G. W., Nagamitsu, M., Nelson, W. L., Peterson, C. J., and Rubenthaler, G. L. 1978. Registration of Sprague wheat. Crop Sci. 18:695.

8. Bruehl, G. W., Sprague, R., Fischer, W. R., Nagamitsu, M., Nelson, W. L., and Vogel, O. A. 1966. Snow molds of winter wheat in Washington. Wash. Agric. Exp. Stn. Bull. 677.

9. Cavelier, M. 1987. La résistance de l'orge d'hiver aux attaques de Typhula incarnata Lasch en fonction du stade de développement et de l'endurcissement des plantes au froid. Parasitica 43:131-153.

10. Cloutier, Y., and Siminovitch, D. 1982. Correlation between cold- and drought-induced frost hardiness in winter wheat and rye varieties. Plant Physiol. 69:256-258.

11. Ergon, A., and Tronsmo, M. 2006. Components of pink snow mould resistance in winter wheat are expressed prior to cold hardening and in detached leaves. J. Phytopathol. 154:134-142.

12. Gaudet, D. A., and Chen, T. H. H. 1987. Effects of hardening and plant age on development of resistance to cottony snow mold ( $\mathrm{Co}$ prinus psychromorbidus) in winter wheat under controlled conditions. Can. J. Bot. 65:1152-1156.

13. Gaudet, D. A., and Kozub, G. C. 1991. Screening winter wheat for resistance to cottony snow mold under controlled conditions. Can. J. Plant Sci. 71:957-965.

14. Iriki, N., Kawakami, A., Takata, K., Kuwabara, T., and Ban, T. 2001. Screening relatives of wheat for snow mold resistance and freezing tolerance. Euphytica 122:335-341.

15. Iriki, N., and Kuwabara, T. 1992. Field resistance of winter wheat varieties to Typhula ishikariensis Biotype $\mathrm{A}, \mathrm{B}$ or $\mathrm{C}$ in artificially infested plots. Jpn. J. Breed. 42:843-852.

16. Iriki, N., Murray, T. D., Jones, S. S., Amano, Y., Salmon, D. F., Shibata, S., Kosareva, I. A., and Kawakami, A. 2001. Breeding cereals for winter survival. Pages 143-155 in: Low Temperature Plant-Microbe Interactions under Snow. N. Iriki, D. A. Gaudet, A. M. Tronsmo, N. Matsumoto, M. Yoshida, and A. Nishimune, eds. Hokkaido Natl. Agric. Exp. Stn., Sapporo, Japan.

17. Iriki, N., Nakajima, T., and Kawakami, A. 2002. Reaction of winter wheat cultivars to artificially inoculated seed-borne pink snow mold. Breed. Sci. 52:231-233.

18. Kawakami, A., and Abe, J. 2003. Method for assessing resistance of wheat to speckled snow mold (Typhula ishikariensis) under controlled environment. J. Gen. Plant Pathol. 69:307-309.

19. Kawakami, A., Matsumoto, N., and Naito, S. 2004. Environmental factors influencing sporocarp formation in Typhula ishikariensis. J. Gen. Plant Pathol. 70:1-6.

20. Kiyomoto, R. K., and Bruehl, G. W. 1977.
Carbohydrate accumulation and depletion by winter cereals differing in resistance to $T y$ phula idahoensis. Phytopathology 67:206-211.

21. Kleijer, G. 1988. Resistance to snow molds of our wheat varieties. Rev. Swiss Agric. 20:6567.

22. Kuwabara, T., Abe, J., Iriki, N., Tsuchiya, T., and Nakajima, T. 1996. New genetic resources for resistance to snow molds in wheat (Triticum aestivum L.). Breed. Sci. 46:409-411.

23. Nakajima, T., and Abe, J. 1990. A method for assessing resistance to the snow mold Typhula incarnata and Microdochium nivale in winter wheat incubated at the optimum growth temperature ranges for the fungi. Can. J. Bot. 68:343-344

24. Nakajima, T., and Abe, J. 1994. Development of resistance to Microdochium nivale in winter wheat during autumn and decline of the resistance under snow. Can. J. Bot. 72:1211-1215.

25. Nakajima, T., and Abe, J. 1996. Environmental factors affecting expression of resistance to pink snow mold caused by Microdochium nivale in winter wheat. Can. J. Bot. 74:17831788.

26. Specht, L. P., and Murray, T. D. 1989. Sporulation and survival of conidia of Cephalosporium gramineum as influenced by soil $\mathrm{pH}$, soil matric potential, and soil fumigation. Phytopathology 79:787-793.

27. Tomiyama, K. 1955. Studies on the snow blight disease of winter cereals. Hokkaido Natl. Agric. Exp. Stn. Rep. 47:1-234.

28. Tronsmo, A. M. 1993. Resistance to winte stress factors in half-sib families of Dactylis glomerata, tested in controlled environment. Acta Agric. Scand. Sect. B Soil Plant Sci. 43:89-96

29. Vji, S., and Tyagi, A. K. 2007. Emerging trends in the functional genomics of the abiotic stress response in crop plants. Plant Biotechnol. J. 5:361-380.

30. Yamaguchi-Shinozaki, K., and Shinozaki, K. 2006. Transcriptional regulatory networks in cellular responses and tolerance to dehydration and cold stress. Annu. Rev. Plant Biol. 57:781803.

31. Yoshida, M., Abe, J., Moriyama, M., and Kuwabara, T. 1998. Carbohydrate levels among winter wheat cultivars varying in freezing tolerance and snow mold resistance during autumn and winter. Physiol. Plant. 103:8-16. 